Article

\title{
Implications of Emerging Vehicle Technologies on Rare Earth Supply and Demand in the United States
}

\author{
Tomer Fishman ${ }^{1, *(\mathbb{D})}$, Rupert J. Myers ${ }^{1,2} \mathbb{1 D}^{\mathbb{D}}$, Orlando Rios ${ }^{3}$ and T.E. Graedel ${ }^{1}$ (i) \\ 1 Center for Industrial Ecology, School of Forestry and Environmental Studies, Yale University, \\ 195 Prospect St., New Haven, CT 06511, USA; Rupert.Myers@ed.ac.uk (R.J.M.); \\ thomas.graedel@yale.edu (T.E.G.) \\ 2 School of Engineering, University of Edinburgh, King's Buildings, Sanderson Building, \\ Edinburgh EH9 3FB, UK \\ 3 Oak Ridge National Laboratory, Oak Ridge, TN 37831, USA; rioso@ornl.gov \\ * Correspondence: tomer.fishman@yale.edu or tomerfishman@gmail.com; Tel.: +1-203-436-4421
}

Received: 4 December 2017; Accepted: 21 January 2018; Published: 25 January 2018

\begin{abstract}
We explore the long-term demand and supply potentials of rare earth elements in alternative energy vehicles (AEVs) in the United States until 2050. Using a stock-flow model, we compare a baseline scenario with scenarios that incorporate an exemplary technological innovation: a novel aluminum-cerium-magnesium alloy. We find that the introduction of the novel alloy demonstrates that even low penetration rates can exceed domestic cerium production capacity, illustrating possible consequences of technological innovations to material supply and demand. End-of-life vehicles can, however, overtake domestic mining as a source of materials, calling for proper technologies and policies to utilize this emerging source. The long-term importing of critical materials in manufactured and semi-manufactured products shifts the location of material stocks and hence future secondary supply of high-value materials, culminating in a double benefit to the importing country. This modeling approach is adaptable to the study of varied scenarios and materials, linking technologies with supply and demand dynamics in order to understand their potential economic and environmental consequences.
\end{abstract}

Keywords: rare earth elements; critical materials; material flow analysis; electric and hybrid vehicles; secondary material supply

\section{Introduction}

Alternative energy vehicles (AEVs) are becoming increasingly common on roads in the United States (US). The rate of adoption of these vehicles has been rising since their introduction into the US market in 1999, even as annual overall sales of passenger vehicles in the US have stalled [1]. In 2014 almost $7 \%$ of passenger vehicles sold had emerging technologies that offer alternatives to internal combustion engine vehicles (ICEVs) [2]. These technologies include hybrid electric vehicles (HEVs) such as the Toyota Prius, plug-in hybrid vehicles (PHEVs) such as the Chevrolet Volt, battery electric vehicles (BEVs) such the Nissan Leaf and Tesla Model 3, and fuel cell vehicles (FCVs) such as the Toyota Mirai. The growth of the market share of these vehicles is expected to continue, and can have a major contribution to reduce environmental impacts such as $\mathrm{CO}_{2}$ emissions [3-5].

These emerging alternative energy technologies involve specialty materials which the vehicle sector previously required only in small amounts, or not at all. These include neodymium and dysprosium for permanent magnets in synchronous electric motors, mischmetal containing rare earth elements for NiMH (Nickel-metal hydride) batteries, lithium and cobalt for lithium-based batteries, and platinum for hydrogen fuel cells. Demands for batteries, permanent magnets, and further uses of these materials are on the rise for wind power, electronics, and other sectors [6-9]. 
However, these materials are subjects to supply restrictions, environmental implications, and supply risks [6,10,11], deeming them to be critical materials [12] with ongoing debates [13] and a growing number of studies of critical materials in various end-uses $[7,14,15]$.

The growth of AEVs will increase demands for such materials, yet US domestic primary production potential is limited, foreign supplies are volatile, and recycling levels of many elements are low $[16,17]$. However, the growing stock of vehicles can serve as an eventual supplier of materials when the vehicles reach the end of their useful life. Research into current and future vehicle fleets and their implications on various materials has been conducted on the global scale and in the UK, Japan, and European countries [18-20], and some studies focused specifically on critical materials in vehicles [21-27]. However, to date these issues have not been explored the context of the US, currently the second largest vehicle market in the world. Focusing on rare earth elements, we are interested in several questions:

- What could be the demand for rare earth elements by the AEV sector until 2050?

- How does historical US domestic production compare to these demands?

- What role could end-of-life vehicles play as a secondary source of these materials?

- How would new critical material intensive-technologies impact supply and demand?

The scope of this study is deliberately limited to understanding the overall orders of magnitude and potential growth patterns of demands and secondary supplies in this sector. At this time, there are multiple yet-unknowable factors that could affect the adoption of AEVs These factors include not only market forces, policies, and technologies, but also emerging societal changes such as car sharing and autonomous vehicles [28], and novel modes of transportation [29]. Forecasts or projections under such conditions may not be wise, and obscure the causes and effects of the questions we are interested in exploring. Rather, to answer these questions we use a controlled scenario modeling approach in a similar vein to the studies cited previously to explore potential inflows, stocks, and outflows of materials in AEVs in the US for 2000-2050. This study focuses on light duty road vehicles, the most numerous of all road vehicle types. Traditional ICEVs are not included due to their relatively lower content of materials of interest.

The last of our questions is especially relevant to innovative sectors like AEVs, in which new developments are sought and embraced at a rapid pace and that can disrupt existing norms. A newly developed aluminum-cerium-magnesium alloy [30,31] serves as a case study to model such scenarios. This alloy, brought to market in November 2016, has several characteristics that make it a compelling case study. It can withstand high temperatures, is highly corrosion resistant, and is more lightweight than the cast iron and cast aluminum alloys currently used in the automotive industry. It is thus a practical alternative to traditional alloys in various automotive end-uses, from specialty drive train components to full replacement of traditional aluminum and iron alloys for lightweighting, enabling us to explore the consequences of the adoption of this alloy in various rates. Moreover, its manufacturing does not require heat treatment, which is a costly and energy intensive process, and its recyclability potential is high and may be a flexible "sink alloy" [32], which is beneficial to our discussion of end-of-life material becoming a supply source. Finally, cerium is found in rare earth ores as a companion metal and coproduct of valuable rare earths such as neodymium, but has lower levels of demand and often remains unused [33]. Further use for cerium could reduce the overburden of mining, making operations more productive [34], and serves as an example of the importance of coproducts to the economics of extraction.

\section{Materials and Methods}

We track the flows and stocks of four vehicle technologies (HEV, PHEV, BEV, and FCV) from 2000 to 2050 in yearly time-steps. 2050 was chosen as the time horizon to enable us to track inflow and outflow trends through nearly two replacement cycles of the vehicle stock, assuming a long-tailed Weibull survival curve as detailed below. The scenario-based approach we utilize is an exploratory if-then setting in which inflows until 2050 follow a growth curve and the in-use stocks and outflows of 
vehicles are estimated using a flow-driven model commonly used in dynamic material flow and stock research [27,35-39] (a conceptual diagram of the model is included in the Supporting Information). We then convert the inflows, outflows, and stocks from vehicle units to the masses of materials contained in them. Uncertainties and sensitivity analyses are examined using Monte Carlo simulations, as in similar dynamic flow-stock models $[38,40,41]$.

\subsection{Vehicle Inflows}

The principal input to the model is the inflows of vehicles to the in-use stock. Inflows from 1999 to 2014 are historical statistics of newly registered alternative-energy light duty vehicles [2]. Inflows are modeled from 2015 to 2050 subject to two premises. The first is that total vehicle sales/inflows in the US will remain at 7.76 million per year, the 1999-2014 average. Despite yearly fluctuations, vehicle inflows have been relatively stable in this period and there is a growing perception that the US may be reaching a state of "peak vehicles" [42]. This observation, together with statistical analysis that did not detect growth or decline trends in US vehicle sales in this period (see the Supporting Information for this statistical analysis), led us to choose this premise. The second premise is that internal combustion as a primary drive technology will be phased out and replaced by a mix of AEVs technologies. This premise is based on the historical encroachment of AEVs into the otherwise stationary vehicle inflow in the US together with the recent announcements by multiple vehicle manufacturers to dramatically transition in the near future to AEV production [43-45] and US states' active efforts in this regard [46].

These two premises describe a scenario in which AEV sales eventually grow from the current 500,000 per year towards a maximum of 7.76 million per year to explore the market penetration that these technologies could reach by 2050 . We model this growth with a logistic curve whose s-shape describes the slow introduction of a new product, rapid growth phase, and slowdown to ubiquity, when sales are mostly to replace old units that reached the end of their useful lives. The logistic curve was fitted to the historical 1999-2014 data with an upper asymptote of 7.76 million:

$$
\operatorname{inflow}(t)=\frac{7.76 \times 10^{6}}{1+e^{-N(t-M)}}
$$

where $t$ is the year (1999-2050) and $M$ and $N$ are fitted coefficients that determine the shape of the s-curve under the restrictions of the historical data and the predefined upper asymptote. $M$ is the inflection point from which growth starts slowing down (fitted value of 2028.44) and $N$ affects the horizontal expansion of the curve (fitted value of 0.1695). In lieu of other inflow trend scenario storylines, we adjust the growth curve assumptions in the Monte Carlo uncertainty analysis, in effect running 10,000 scenarios of vehicle sales trends, and systematically explore the adjusted assumptions' effects on the results.

The share $v$ of vehicles of technology $i$ in the total inflows is set to change over time:

$$
\operatorname{inflow}_{i}(t)=\operatorname{inflow}(t) \times v_{i, t}
$$

Historical shares are used up to 2014. Future values of $v_{i, t}$ are based on International Energy Agency's (IEA) BLUE map scenario of technology transitions $[3,47]$ that proposes pathways for AEVs to contribute to a $50 \%$ reduction of energy-related $\mathrm{CO}_{2}$ emissions by 2050 compared to 2005 . The BLUE map does not describe the types of batteries used with each drive technology. We therefore dynamically assigned battery technologies to the four drive technologies, as described in the Supporting Information. Through the Monte Carlo simulations we alter the shares of vehicle technologies over time and investigate the uncertainties of these assumptions and the sensitivity of the results to them, as discussed in the Supporting Information. 


\subsection{Vehicle Stocks and Outflows}

The set of equations that govern the dynamic vehicle stock-flow model are:

$$
\begin{gathered}
\operatorname{stock}_{i}(t)=\sum_{\tau=t_{0}}^{t}\left[\operatorname{inflow}_{i}(\tau) \times\left(1-f\left(t-\tau, a_{1}, a_{2}\right)\right)\right] \\
\operatorname{nas}_{i}(t)=\operatorname{stock}_{i}(t)-\operatorname{stock}_{i}(t-1) \\
\operatorname{outflow}_{i}(t)=\operatorname{inflow}_{i}(t)-\text { nas }_{i}(t)
\end{gathered}
$$

where $t$ is the year; $\tau$ is an index of previous years so that $(t-\tau)$ is the time that has passed since inflow $(\tau)$ occurred; $\operatorname{stock}_{i}(t)$ is a convolution, the sum of the products of inflow $w_{i}(\tau)$ times the value of survival function $f$ for each inflow at time $(t-\tau) ; f\left(t-\tau, a_{1}, a_{2}\right)$ is a Weibull cumulative distribution function, commonly used to describe survival and failure of end-use stocks [48]:

$$
f\left(t, \tau, a_{1}, a_{2}\right)=1-e^{-\left(\frac{t-\tau}{a_{2}}\right)^{a_{1}}}
$$

in which $a_{1}$ is a shape parameter and $a_{2}$ is a scale parameter. We are not aware of previous estimates for the Weibull function parameters for AEVs in the US, so we used averaged parameters for Toyota Prius models in Japan [27] and parameters calculated by us for the US passenger car fleet [49] to set $a_{1}=2.43$ and $a_{2}=16.94$ which provide a survival curve of about $75 \%$ after 10 years, $50 \%$ after 15 years, and $10 \%$ after more than 20 years. (see the Supporting Information for details, including uncertainty analysis for these parameters). nas $i_{i}(t)$ is the net addition to the stock, the difference in the stock between two years, which is by definition also equal to the difference between inflow and outflow in a year, allowing outflow $(t)$ to be calculated. inflow $(\tau)$, outflow $(\tau)$, and $n a s_{i}(\tau)$ are measured in vehicles/year whereas $\operatorname{stock}_{i}(\tau)$ is measured in number of vehicles.

\subsection{Material Intensities and the Mass of Materials in Vehicles}

Converting inflows, outflows, and stocks from number of vehicles to masses of materials can be challenging. The material composition of a vehicle varies based on many factors such as manufacturer, model, production year, trim level, after-market modifications, and wear and tear. The necessary data and effort to account for all these factors is tremendous. However, only the sum, not the variance within the fleet, is of interest for our objectives. We therefore use material intensity coefficients, typical masses of materials in an average vehicle representative of each technology. We compiled material intensity data for vehicles to represent the range of contemporary light duty vehicles in the US, synthesizing multiple sources $[23,24,26,27,50-63]$. The main vehicle components are covered: the vehicle body, electric motor(s), generator, and battery for all eight technologies; internal combustion engine and powertrain for HEV and PHEV; and fuel cells for FCV. Smaller components such as automatic windows or navigation and audio systems are not included even though they may include some amounts of critical materials $[25,55]$ because of their variability and uncertain future trends. Non-metallic elements such as plastics and glass are also not considered.

This culminated in typical material intensity figures for 20 elements for the eight AEV drive and battery technology combinations and for ICEVs and the full dataset and compilation methods are detailed in the Supporting Information. The sector-level total mass of material $j$ in year $t$ is calculated by multiplying the material intensity by the number of vehicles:

$$
\operatorname{mass}_{j}(t)=\sum_{i}\left(M I_{i, j} \times \operatorname{vehicles}_{i}(t)\right)
$$

$M I_{i, j}$ is the material intensity of material $j$ in a single vehicle of technology $i$; and vehicles $i(t)$ can be swapped with inflow $(t)$, outflow $w_{i}(t)$ (measured in mass/year), or stock $(t)$ (measured simply as mass). Results were calculated for all 20 metals. Only the results related to rare earth elements are 
further discussed in the study, but the remaining results are included in the Supporting Information for reference and comparison.

It is plausible to assume that technologies and their related material intensity values may change over time, yet these types of changes can be influenced by multiple contradicting factors. As a consequence, predictions would be highly uncertain, especially on a time horizon of several decades. We investigated the effects of random changes in material intensities using Monte Carlo simulations to understand the effects of such inherent uncertainties on the results as described in the Supporting Information, but for the main case study we keep material intensities unchanged as a baseline scenario, and introduce controlled changes as the setups of two further scenario sets presented below.

\subsection{Scenarios of Technological Change}

The consequences of technological change on the demand and supply of critical materials is illustrated by the introduction of a recently developed aluminum-cerium-magnesium ( $\mathrm{AlCeMg}$ ) alloy $[30,31]$ in two scenarios. In the Fe substitution scenario set, a rate $r(1-100 \%)$ of the AlCeMg alloy is substituted for cast iron in internal combustion engines of cars sold from 2025 onwards. There is no technical restriction to substitute iron only in internal combustion engines and not in other components. Rather, this is a modeling choice to explore consequences related to specific vehicle technologies-in this case, only hybrids and plug-in hybrids. In contrast, in the Al substitution scenario set we substitute the AlCeMg alloy at a rate $r$ for cast aluminum, up to the entire aluminum in all vehicle components, in all vehicle technologies. The formulas in Table 1 are used in these two scenarios.

Table 1. Comparison of the material intensities in the three scenarios: the baseline scenario, the substitution of cast iron scenario set, and substitution of cast aluminum scenario set. $M I_{i, j}(j=F e, A l, M g, C e)$ is the material intensity of each material; $M I_{i, F e, I C E}$ is the material intensity of iron in an internal combustion engine; $r$ is the substitution rate; $R D_{F e}$ and $R D_{A l}$ are the density ratios of the AlCeMg alloy $\left(2500 \mathrm{~kg} / \mathrm{m}^{3}\right)$ to the densities of cast iron $\left(7300 \mathrm{~km} / \mathrm{m}^{3}\right)$ and high-volume cast aluminum $\left(2700 \mathrm{~kg} / \mathrm{m}^{3}\right)$, respectively, e.g., $R D_{\mathrm{Fe}}=\frac{D_{\mathrm{AlCeMg}}}{D_{\mathrm{Fe}}}=\frac{2500}{7300}$.

\begin{tabular}{cccc}
\hline Material & Baseline Scenario & Fe Substitution Scenario & Al Substitution Scenario \\
\hline $\mathrm{Fe}$ & $M I_{i, F e}$ & $M I_{i, F e}-\left[M I_{i, F e, I C E} \times R D_{F e} \times r\right]$ & $M I_{i, F e}$ \\
$\mathrm{Al}$ & $M I_{i, A l}$ & $M I_{i, A l}+\left[M I_{i, F e, I C E} \times R D_{F e} \times 0.8 r\right]$ & $M I_{i, A l} \times[1-r]+\left[M I_{i, A l} \times R D_{A l} \times 0.8 r\right]$ \\
$\mathrm{Mg}$ & $M I_{i, M g}$ & $M I_{i, M g}+\left[M I_{i, F e, I C E} \times R D_{F e} \times 0.1 r\right]$ & $M I_{i, M g}+\left[M I_{i, A l} \times R D_{A l} \times 0.1 r\right]$ \\
$\mathrm{Ce}$ & $M I_{i, \mathrm{Ce}}$ & $M I_{i, C e}+\left[M I_{i, F e, I C E} \times R D_{F e} \times 0.1 r\right]$ & $M I_{i, C e}+\left[M I_{i, A l} \times R D_{A l} \times 0.1 r\right]$ \\
\hline
\end{tabular}

Because we analyze aggregate sectoral metal demands on the country scale, the rate, $r$, can be equally interpreted as replacing $r \%$ of material in all cars or as replacing all material in $r \%$ of cars, and so is synonymously a substitution rate or a market penetration rate. Values of $r$ in a given production year could fluctuate due to market forces, supply restrictions, competing technologies, and a multitude of other variables. This study is aimed at exploring long-term orders of magnitude and trend patterns rather than markets, and the added complexity of introducing such factors would obscure these main objectives. For ease of interpretation, $r$ is kept fixed over time and we present several cases of different $r$ values for each scenario.

\section{Results}

\subsection{Vehicle Trends}

The inflows, outflows, and in-use stock of vehicles are presented in Figure 1. Confidence intervals were calculated through Monte Carlo simulations that show the combined effects of variations to the baseline scenario settings, as explained in the methods section. The inflows (sales) of vehicles are characterized by successive waves of technological changes (Figure 1a). HEV sales are modeled to decline from the 2030s and PHEV sales stabilize in the 2040s. BEV and later FCV sales grow until 2050, even as the overall growth of inflows slows down from 2030 towards 7.5 million ( \pm 1.5 million) vehicles 
per year in 2050. The in-use stock of AEVs (Figure 1b) grew to over 3.5 million in 2014 and to almost 100 million ( \pm 20 million) by 2050 . Vehicles of the HEV NiMH technology dominate the in-use stock in early years but become negligible by 2050 . HEV Li-ion and Li-poly still consist of almost $20 \%$ of the stock in 2050 despite their inflows declining since 2030, signifying the relatively long use phase of vehicles. PHEV becomes the main in-use technology from 2030, comprising over $40 \%$ of the stock from the late 2040s. BEV is the second most common technology in that period, with a $25 \%$ share, followed by the three FCV technologies with a total of $12 \%$. Total annual outflows of end-of-life vehicles (Figure 1c) grow rapidly year-on-year. Outflows exceed a million vehicles per year $( \pm 250,000)$ starting in the 2030s and over 5 million per year ( \pm 1 million) by 2050. As inflows stabilize, the ratio of inflows to outflows changes. In the 2010s, for every 10 vehicle inflows 1 in-use vehicle reaches its end of life, and in 2050 the ratio is 10:7. Outflows of HEV NiMH peak at nearly 400,000 units per year in the early 2040s, and by 2050 decline to 150,000/year, nearly the same as in 2022. In comparison, outflows of the other technologies grow throughout 2050.
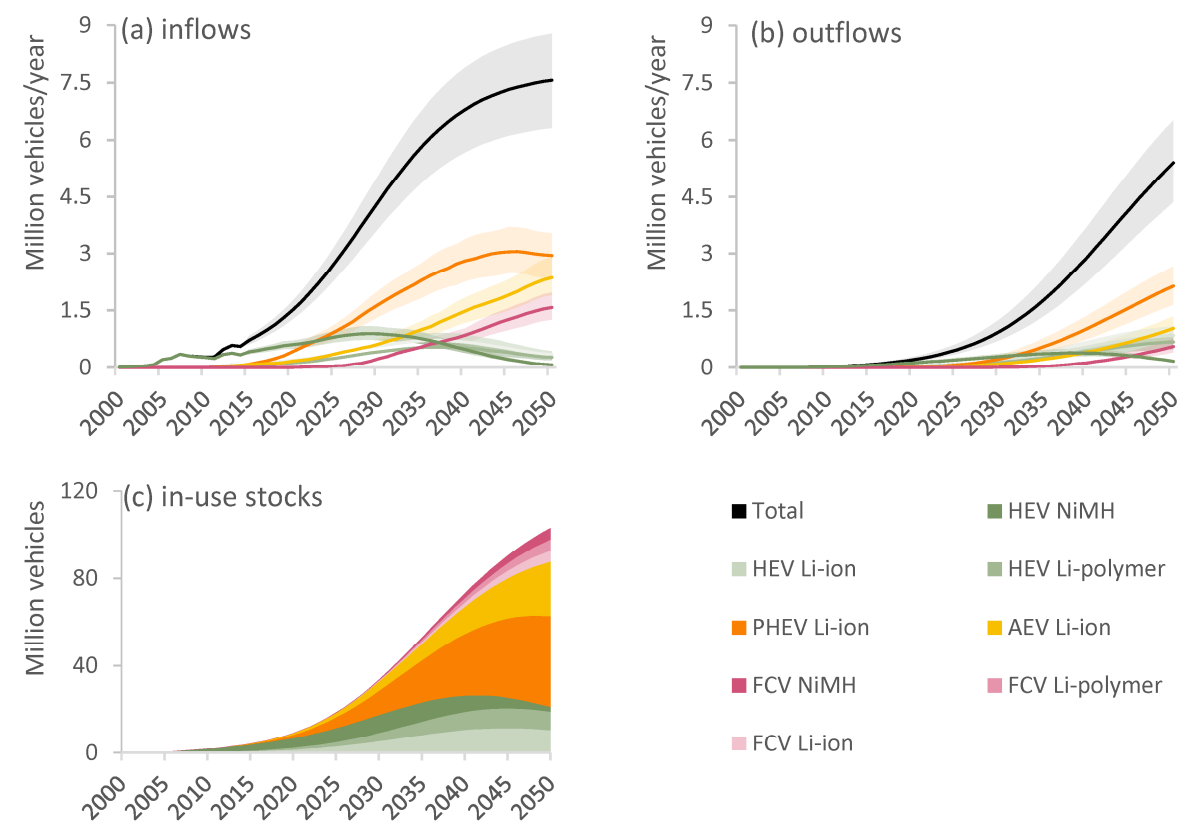

Figure 1. Inflows (a); outflows (b); and in-use stocks (c) of alternative energy passenger vehicles in the US, 2000-2050 by technology. Notes: panels (a,b) show the three FCV types aggregated to a single category for clarity. The flows panels $(\mathbf{a}, \mathbf{b})$ present $5 \%$ and $95 \%$ confidence intervals calculated with Monte Carlo simulations (see Supporting Information for details). HEV-hybrid electric vehicle, PHEV—plug-in hybrid electric vehicle, BEV—battery electric vehicle, FCV—fuel cell vehicle. Note the different ordinal scales of the flows and stocks figures.

\subsection{Supply and Demand of Rare Earth Elements}

The demands of rare earth elements to satisfy AEV sales correspond to the modeled inflows of material in AEVs. In turn, outflows of end-of-life vehicle form a potential secondary supply source of these materials. The demand and secondary supply trends of three main rare earth elements are presented in Figure 2. For reference, recent (2012-2015) domestic average production levels (broken down by elemental equivalents) are presented as straight horizontal lines in Figure 2 to provide a scale for the demand and secondary supply trends modeled in this study, and to display a hypothetical potential of domestic primary supply to support rare earth demands. This primary supply potential is hypothetical, because as of 2017 there is no longer any primary supply of rare earths in the US. The sole domestic rare earth production site, the Mountain Pass mine in California, historically peaked at about 
$20 \mathrm{Gg}$ /year of rare earth oxides in the early 1990s [64] but closed in 2002. It resumed operations for 4 years in 2012-2015 with an annual average production of around $5 \mathrm{Gg}$ /year [65].

Rare earth element demands by AEVs present differing trends depending on the technologies in which they are used. Neodymium inflows and outflows are the largest because neodymium is required for electric motor permanent magnets in all AEV technologies (Figure 2a). In our scenario setting, neodymium demand slows in the 2040s together with AEV sales, reaching over $5 \mathrm{Gg}$ /year. To put this demand into scale, in 2012-2015 about $0.5 \mathrm{Gg}$ /year of elemental neodymium were domestically produced in the US, enough to have hypothetically fulfilled the demands of AEVs for the metal until 2014. In comparison, the recovery potential of neodymium from end-of-life vehicles is increasing, and can overtake historic domestic average primary supply by around 2030. By 2050 it is more than seven times larger than 2012-2015 average primary supply levels. In a hypothetical situation in which domestic mining resumed at 2012-2015 levels and secondary material recovery were fully utilized, the combined source could supply at least $35 \%$ of annual AEV demand in 2030, and up to $80 \%$ of demand in 2050. Dysprosium (figure in the Supporting Information) has inflow and outflow curves similar to neodymium because of their companionship in permanent magnets, albeit at smaller scales. Dysprosium demands rise from $25 \mathrm{Mg}$ /year in 2015 to over $300 \mathrm{Mg}$ /year from 2040. It was not mined in the US, so domestic supply could only come from secondary recovered materials, potentially providing a range from $10 \%$ of the demand in 2020 to more than $60 \%$ in 2050 .

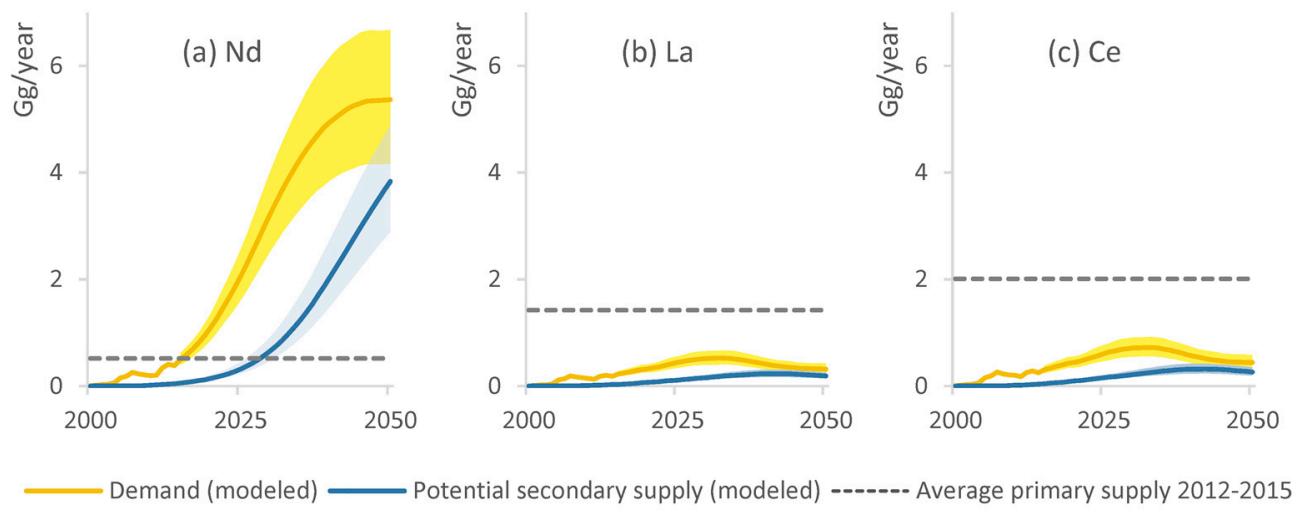

Figure 2. US alternative energy vehicles (AEV) demands of three rare earth elements (a) neodymium; (b) cerium; and (c) lanthanum and potential secondary supplies from end-of-life AEVs with 5\% and 95\% confidence intervals. Historical (2012-2015) average domestic primary production levels are shown for comparison.

In comparison, lanthanum (Figure 2b), cerium (Figure 2c), praseodymium, terbium, gadolinium, and erbium (Figures in the Supporting Information) have similar inflow and outflow trajectories to each other. They are all used in small amounts in NIMH batteries in a mischmetal alloy [66], and their inflows peak and decline in the early 2030s as other battery technologies overtake NiMH. By 2050, the demands for these materials decline down to 2020 levels. Outflows of these materials peak in the 2040s and are insufficient as a supply source on their own. However, if primary production resumed at 2012-2015 levels, demands would not exceed 50\% of this hypothetical primary supply even at their peak (note that terbium and erbium were not produced in the US, and are considered noncrucial trace elements in mischmetal). A theoretical combined primary and secondary supply potential of these materials would far exceed demands.

As seen in Figure 2, this presents an odd situation in which there is a mismatch between materials in high demand (neodymium) and materials in excess of supply (lanthanum and cerium). This visualizes in relative microcosm an acknowledged phenomenon of a "balance problem" $[67,68]$ in the coproduction of rare earth elements. Since rare earth elements are geologically found together, the higher abundance of the less valuable lanthanum and cerium create economic and environmental 
burdens on the extraction of neodymium, as much of these two elements get discarded as overburden and tailings. Were cerium or lanthanum demands higher, the efficiency of rare earth extraction could be improved.

\subsection{Introduction of AlCeMg Alloy Technology}

The demands of cerium can potentially change by orders of magnitude by its utilization in the newly developed AlCeMg alloy. Figure 3 compares four penetration rates $(0 \%, 1 \%, 10 \%$, and 100\%) and their effects on cerium, magnesium, aluminum, and iron demands in the Fe substitution and $\mathrm{Al}$ substitution scenarios. Three exemplary years are shown: 2025, when the alloy is introduced in our scenarios; 2035, the peak inflow of AEVs with internal combustion engines; and 2050. Overall, more light-weighting of the vehicle fleet is achieved in the Fe substitution scenario set due to iron's higher density. If $1 \%$ of cast iron engine components are replaced with the new alloy, annual demand for Ce would increase by at least $20 \%$ per year (increase of $100-200 \mathrm{Mg} /$ year). This substitution would also induce 10-20\% increases in magnesium demands, but the effects on iron and aluminum are insignificant. In comparison, full substitution $(100 \%)$ would induce a 20 -fold increase in cerium demand in 2025 ( $12 \mathrm{Gg}$ /year), up to a range of 18-22 Gg/year in 2035-2050, 30 to 40 times higher than the equivalent baseline demands. These scales exceed those of neodymium. In parallel, aluminum demand would increase by $15-25 \%$ per year and iron demand would decrease by around 10\% per year.

In the $\mathrm{Al}$ substitution scenario set, cerium demands are higher at every substitution rate. Replacement of $1 \%$ of aluminum components with the alloy increases the demand for cerium by $50 \%$ in 2025 and up to almost triple the baseline demand in 2050. Magnesium demand would increase by around $50 \%$ per year but the overall aluminum reduction would be inconsequential. Full substitution $(100 \%)$ would decrease annual aluminum demand by $25 \%$, while cerium demands would increase to $33 \mathrm{Gg} /$ year in 2025 . This is not only a 50 -fold increase over the baseline, but also higher than any yearly cerium demand in the Fe substitution scenario set. At this substitution rate, cerium demand keeps increasing up to almost $80 \mathrm{Gg}$ /year in 2050 (180 times the baseline demand in that year).

(a) Fe substitution scenario

(b) Al substitution scenario

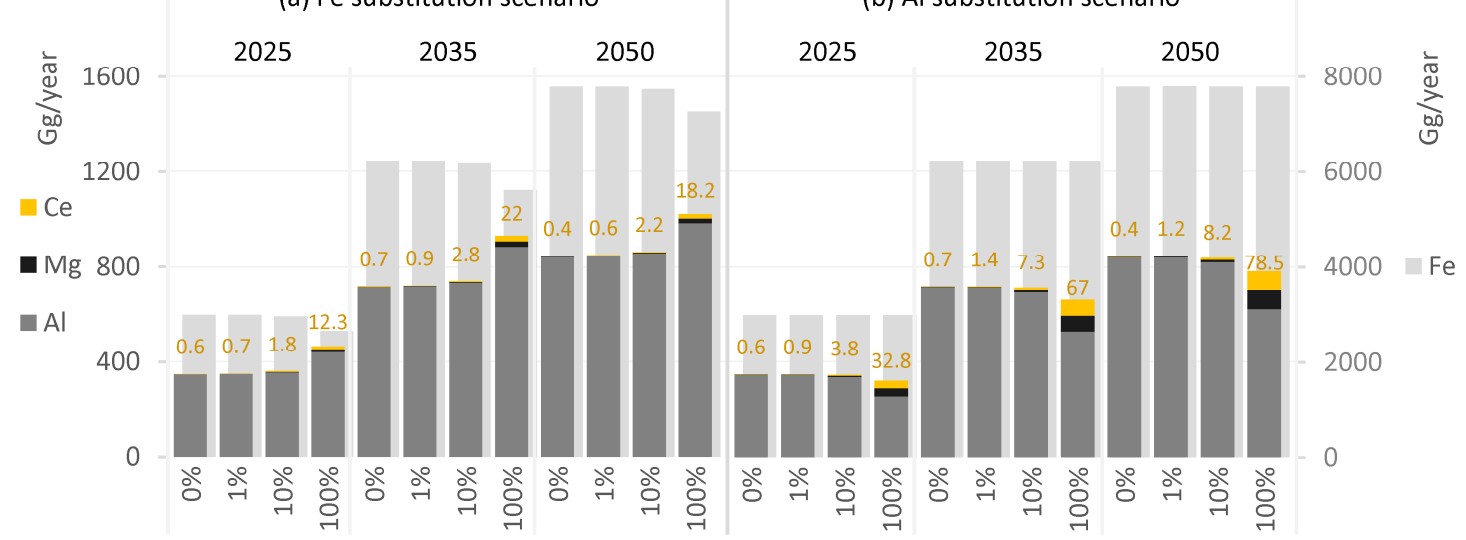

Figure 3. Comparisons of demands (in $\mathrm{Gg}$ ) for $\mathrm{Ce}, \mathrm{Mg}$, and $\mathrm{Al}$ (left-hand axis) and Fe (right-hand axis) in the Fe substitution scenario (a) and Al substitution scenario (b) in three years $(2025,2035,2050)$ at different substitution rates. $0 \%$ is equivalent to the baseline scenario. Cerium demand is shown in numbers at the top of each bar.

\subsection{Can Demands and Supplies Reach Equilibrium?}

After examining the effects of minimum (1\%) and maximum (100\%) substitution rates in both scenarios, we now proceed to a thought experiment to explore which substitution rates can fully utilize—and don't exceed-the historical 2012-2015 average yearly primary domestic supply of cerium (about $2 \mathrm{Gg} /$ year). A $6 \%$ iron substitution scenario or a $2 \%$ aluminum substitution scenario (Figure $4 \mathrm{a}, \mathrm{d}$, 
respectively) would do so, at first glance suggesting that a market for domestic cerium could exist, even if primary cerium was exported for manufacturing and reimported as vehicles or vehicle components. However, in the $6 \%$ Fe substitution scenario this new demand is stable only for a few years because of the reductions in HEVs and PHEVs incorporating combustion engines in the 2040s, and by 2050 demands return to 2025 levels. In effect, the Fe substitution scenario set resembles the peak and decline of cerium in the baseline scenario (Figure 2c), albeit delayed and at higher levels. On the other hand, in the $2 \% \mathrm{Al}$ substitution scenario demands remain more or less stable until 2050 because aluminum components are not related to any one vehicle technology that may be phased out. This suggests that cast iron substitution is only a medium-term solution to excess supply of cerium whereas the aluminum scenario could be a longer-term solution.

However, increased inflows of cerium also have an effect on its eventual outflows, which would increase in the above scenarios to about $1.5 \mathrm{Gg}$ /year in 2050 . While this means that secondary supply would become a more substantial source and add diversity to domestic supply capacity, it also risks excess supply if both mining and recycling operate at full capacity. The grey-shaded areas in Figure 4 represent this hypothetical mixed cerium supply with primary production rates at the 2012-2015 levels. Its top signifies the maximum mixed supply that could be utilized in such a scenario.
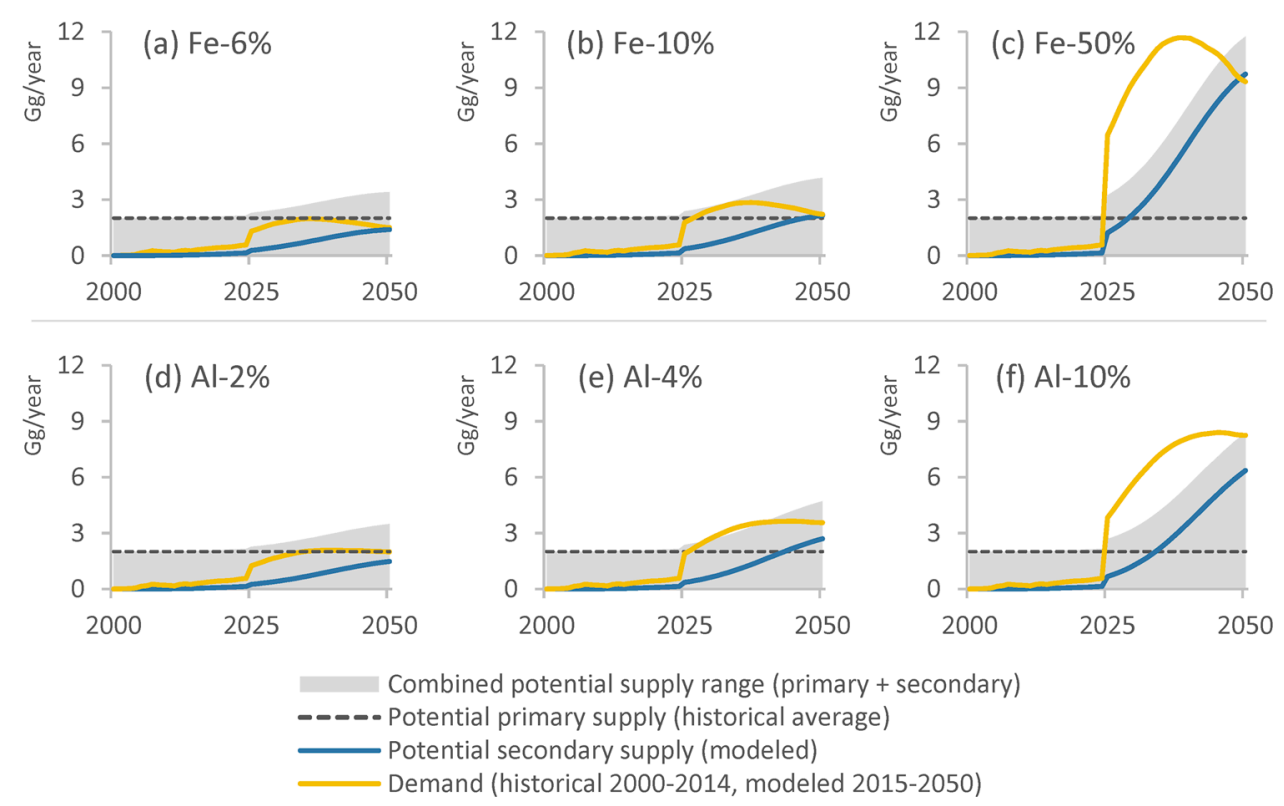

Figure 4. Comparison of the demands and potential domestic supplies of cerium, 2000-2050 in the scenarios in which an AlCeMg alloy replaces Fe (panels $\mathbf{a}-\mathbf{c}$ ) or $\mathrm{Al}$ (panels $\mathbf{d}-\mathbf{f}$ ) at various substitution rates. The potential primary supply is a hypothetical supply scenario based on 2012-2015 average domestic primary production, and the grey-shaded area represents a hypothetical domestic supply of both primary and secondary cerium from AEVs.

Perhaps counterintuitively, higher substitution rates than previously described would be required to fully utilize both primary and secondary supplies of cerium for the longest period of time. Optimal rates are a $10 \%$ Fe substitution scenario or $4 \% \mathrm{Al}$ substitution scenario (Figure $4 \mathrm{~b}$,e). These rates increase inflow demands but also produce more outflows in the long run. In the iron case, demands exceed primary production for a few years, but end-of-life cerium quickly grows to complement primary production. However, this approach would only be successful for a few years until around 2035 as ICE engine-carrying AEVs (HEV and PHEV) get phased out. From then on, the excess combined supply increases and by 2050, the combined cerium supply would be twice the demand. The $4 \%$ Al substitution scenario would allow to nearly balance demands and supplies for a longer period 
(until 2040). The subsequent stabilization of demand would result in smaller excess supply potentials than the corresponding optimum in the $10 \%$ Fe substitution scenario.

Substitution rates higher than $10 \%$ in the Fe substitution scenario and $4 \%$ in the Al substitution scenario would overshoot the hypothetical combined domestic supply capacities. The higher the rates, the wider the gap between demand and supply would grow and the longer this period would be. This would also lead to secondary supply eventually overtaking primary production, resembling the types of trends we see for neodymium, demonstrated in Figure 4c,f. The peak demand for cast iron substitution in the Fe substitution scenario can be clearly seen in panel f, which also shows that in this scenario with such high (50\%) substitution rates, near the end of the examined period the imbalance would again shift to an excess supply potential.

\section{Discussion}

\subsection{Outlook for REEs in AEVs}

The ongoing transition of material stocks from the natural environment to the anthroposphere has been an active area of concern, but tends to focus on the global scale and widely used bulk materials such as copper and aluminum [41,69-71] although lithium has also been receiving increased attention recently [72-74]. Our results shed light on the accumulation of critical materials in the in-use stock of vehicles in the US to levels that could soon compete with and may exceed traditional mines. In the case of neodymium, the in-use stock in AEVs grows in 50 years from virtually nonexistent to nearly $75 \mathrm{Gg}$, equivalent to about 50\% of the United States' 2017 in-ground reserves [65]. However, the reality of rare earths supply and demand is more complex, as exemplified by the closing of the US's sole primary production site in 2015 even though its annual neodymium extraction could have in theory supplied the entire demand for the nearly half million AEVs that were domestically sold in that year. Low prices, overwhelming competition from China, and high overburdens were among the reasons for its failure.

Our flow and stock scenarios join a growing literature of studies with long time horizons of vehicles and the materials in them $[18,19,21,22,26,27]$. The if-then scenario approach inherently includes assumptions and simplifications that omit various factors. Our scenarios, based on current trends and growth premises, describe certain paths out of many plausible futures. They are thus not intended to be forecasts of the future or replacements for corporate-level assessments to provide, for example, a recommendation whether to resume domestic primary production. Nevertheless, analysis of the Monte Carlo simulations reveals that in general the results are most sensitive to two variables: inflow $(t)$ and $M I_{i, j}$ (due to lack of space, the full analysis is detailed in the Supporting Information). This analysis suggests that the fundamental storyline of our scenarios, that AEV sales will continue to increase, lead to certain important trends that require attention for long-term resource management. The exact pattern of growth may vary but by "connecting the dots" between end-use trends, resources, and new technological developments, our flow-stock scenarios uncover the orders of magnitude in question and can help promote a discussion of demands and supplies of REEs in relation to AEV growth.

End-of-life vehicles could indeed become viable "urban mines", and so the upcoming waves of secondary materials available from AEVs call for heightened focus to develop the technologies, policies, and infrastructure that would enable using these materials to their full potential, especially as global primary supply options are slow to respond to increases in demands [75]. From a technological perspective, further knowledge and know-how to extract and recycle critical materials from end-of-life vehicles is required. Better yet, the design and production of backward- and forward-compatible components for reuse should be encouraged. Unlike traditional mines, secondary sources are dispersed in millions of privately owned vehicles. Proper policies and infrastructure to collect and manage end-of-life vehicles at the necessary scale currently do not exist, and the economies of such an endeavor are far from trivial. Such infrastructure could originate with vehicle manufacturers interested in securing a relatively steady domestic supply of materials. However, it could also provide an opportunity for other private and public-sector initiatives. Combined with demands of other end-uses 
and other countries, it would seem that the label of criticality for these materials due to primary supply constraints and risks would be warranted for the foreseeable future.

\subsection{Shifting Stocks}

These observations not only relate to the flow of materials from the environment to the anthroposphere but across national economies too. The majority of critical materials that we examined originate outside the US and their accumulation acts as a long-term cross-border transition in the ownership of valuable materials. In this sense, international trade shifts the balance in the stock of resources-an import of a vehicle is not only an import of a personal transportation device, but is also an import of material that may reduce future dependence on foreign primary supplies. The export of environmental pressures related to material consumption from affluent developed countries to developing countries has been well documented through footprint studies [76], which show that tailings and other low-value materials remain in countries of origin while the products of these mines benefit consumer countries [77]. The second side of this coin is that the high-value materials remain and accumulate in consumer countries even after the original intended use of these materials has ended, providing a potential double benefit. This topic should be elaborated further in the discussion of international resource flows.

\subsection{Technological Changes}

Although supply disruptions have been an active subject of study, there has been less focus on demand-side disruptions. The technical and economic benefits of a useful new technology could easily bring about a demand that would induce further demand of primary sources. The $\mathrm{AlCeMg}$ alloy serves as an example of such a technology and its long-term consequences to demands of critical materials. Theoretically, the adoption rate of this alloy could range from none to full replacement of currently used iron and aluminum alloys. Manufacturers' decisions as to which components to replace and at what rates could be based on a multitude of unpredictable factors, including cerium prices, availability, scalability, and so on. In practice, the choice of which vehicle components and materials to substitute is crucial to demands and secondary supply trends, as seen in the Fe substitution scenario which does not sustain its new demands because of the shift away from cast iron-based vehicle components.

Nevertheless, our scenarios show that even relatively low penetration rates of such a new technology could transform an underused companion metal into one whose demands easily exceed supplies. Even in lower rates of substitution, which could describe a single car manufacturer adopting the new technology, or the alloy replacing just a single type of vehicle component, the new inflows are significantly higher than the baseline inflows, forming a step change in cerium demand. Concurrently a similar change would occur in outflows, caused merely from new vehicles that end their useful life within the year the technology is introduced (due to car accidents for example). This signifies that proper cerium supply and recovery systems would need to be in place to satisfy the unprecedented new demands and secondary supply potentials from day one. Maintaining a sustained equilibrium between demand and supply, even when utilizing end-of-life sources, was shown to be unviable using the simple fixed substitution rates utilized in this study. Rather, our results suggest that AlCeMg alloy use can be ramped up slightly over time after introduction into the market due to increased secondary supply of cerium, which should be considered by policy makers and technology suppliers. The new alloy has applications in other sectors such as aviation, compounding the factors to be taken into account. While beyond the objectives of this study, a dynamic equilibrium could be explored to better understand the factors at play [34]. Such a dynamic equilibrium may be achievable through constant monitoring of trends and control over substitution rates vis-à-vis primary production, recycling, and stockpiling of ores and scrap, and it is unclear whether market price mechanisms would suffice to naturally guide these actions.

It should be noted, however, that demand-side disruptions could also occur in the opposite direction, should sudden and dramatic reductions in demand for a material such as neodymium due to 
substitution of permanent magnet-based motors with induction motors take place [13]. At the product level, even production of popular models like the Chevrolet Volt PHEV may be halted due to company decisions [78], affecting material demands. Recent discussions of concepts such as autonomous vehicles and alternative car ownership models may be even more disruptive, and compound the difficulty of forecasting material supply and demands in this sector. Similar changes can be expected for materials in other emerging sectors in which new technologies are relatively rapidly developed and incorporated. Because such innovations continually occur, the consequences to primary and secondary supply sources call for enduring investigation. The scenario-based modeling approach that we employ in this study is easily adaptable to study varied scenarios that link technologies with supply and demand dynamics in order to understand the associated potential economic and environmental consequences.

Supplementary Materials: The following are available online at www.mdpi.com/2079-9276/7/1/9/s1, Further information about the modeling framework, compilation of vehicle material intensities, modeling of the inflows of AEVs, results of materials not discussed in the article, data uncertainties and Monte Carlo simulations, and global sensitivity analysis.

Acknowledgments: This work was supported by the Critical Materials Institute, an Energy Innovation Hub funded by the U.S. Department of Energy, Office of Energy Efficiency and Renewable Energy, Advanced Manufacturing Office.

Author Contributions: T.F., R.J.M., O.R. and T.E.G. conceived and designed the experiments; T.F. performed the experiments; T.F., R.J.M., and O.R. analyzed the data; T.F., R.J.M., O.R. and T.E.G. wrote the paper.

Conflicts of Interest: The authors declare no conflict of interest.

\section{References}

1. U.S. Department of Transportation. National Transportation Statistics; Bureau of Transportation Statistics: Washington, DC, USA, 2016.

2. U.S. Department of Energy. HEV Sales by Model. Available online: https://www.afdc.energy.gov/uploads/ data / data_source/10301/10301_hev_sales.xlsx (accessed on 27 January 2017).

3. International Energy Agency. Technology Roadmap: Electric and Plug-In Hybrid Electric Vehicles (2011 Update); IEA Publications: Paris, France, 2011.

4. Miotti, M.; Supran, G.J.; Kim, E.J.; Trancik, J.E. Personal Vehicles Evaluated against Climate Change Mitigation Targets. Environ. Sci. Technol. 2016, 50, 10795-10804. [CrossRef] [PubMed]

5. U.S. Energy Information Administration. Annual Energy Outlook 2017; U.S. Energy Information Administration: Washington, DC, USA, 2017. Available online: https:/ / www.eia.gov/ outlooks/aeo (accessed on 4 May 2017).

6. U.S. Department of Energy. 2011 Critical Materials Strategy. 2011. Available online: https:/ / energy.gov / epsa/downloads /2011-critical-materials-strategy (accessed on 6 July 2017).

7. Du, X.; Graedel, T.E. Global In-Use Stocks of the Rare Earth Elements: A First Estimate. Environ. Sci. Technol. 2011, 45, 4096-4101. [CrossRef] [PubMed]

8. Sprecher, B.; Daigo, I.; Murakami, S.; Kleijn, R.; Vos, M.; Kramer, G.J. Framework for Resilience in Material Supply Chains, With a Case Study from the 2010 Rare Earth Crisis. Environ. Sci. Technol. 2015, 49, 6740-6750. [CrossRef] [PubMed]

9. Imholte, D.D.; Nguyen, R.T.; Vedantam, A.; Brown, M.; Iyer, A.; Smith, B.J.; Collins, J.W.; Anderson, C.G.; O'Kelley, B. An assessment of U.S. rare earth availability for supporting U.S. wind energy growth targets. Energy Policy 2018, 113, 294-305. [CrossRef]

10. Graedel, T.E.; Harper, E.M.; Nassar, N.T.; Nuss, P.; Reck, B.K. Criticality of metals and metalloids. Proc. Natl. Acad. Sci. USA 2015, 112, 4257-4262. [CrossRef] [PubMed]

11. Massari, S.; Ruberti, M. Rare earth elements as critical raw materials: Focus on international markets and future strategies. Resour. Policy 2013, 38, 36-43. [CrossRef]

12. Eggert, R.G. Minerals go critical. Nat. Chem. 2011, 3, 688-691. [CrossRef] [PubMed]

13. Lovins, A. Clean energy and rare earths: Why not to worry. Bulletin of the Atomic Scientists. 2017. Available online: https:/ thebulletin.org/clean-energy-and-rare-earths-why-not-worry10785 (accessed on 17 July 2017). 
14. Du, X.; Graedel, T.E. Uncovering the end uses of the rare earth elements. Sci. Total Environ. 2013, 461-462, 781-784. [CrossRef] [PubMed]

15. Shigetomi, Y.; Nansai, K.; Kagawa, S.; Kondo, Y.; Tohno, S. Economic and social determinants of global physical flows of critical metals. Resour. Policy 2017, 52, 107-113. [CrossRef]

16. Ciacci, L.; Reck, B.K.; Nassar, N.T.; Graedel, T.E. Lost by Design. Environ. Sci. Technol. 2015, 49, $9443-9451$. [CrossRef] [PubMed]

17. Graedel, T.E.; Allwood, J.; Birat, J.-P.; Buchert, M.; Hagelüken, C.; Reck, B.K.; Sibley, S.F.; Sonnemann, G. What Do We Know About Metal Recycling Rates? J. Ind. Ecol. 2011, 15, 355-366. [CrossRef]

18. Fridstrøm, L.; Østli, V.; Johansen, K.W. A stock-flow cohort model of the national car fleet. Eur. Transp. Res. Rev. 2016, 8, 22. [CrossRef]

19. Modaresi, R.; Pauliuk, S.; Løvik, A.N.; Müller, D.B. Global Carbon Benefits of Material Substitution in Passenger Cars until 2050 and the Impact on the Steel and Aluminum Industries. Environ. Sci. Technol. 2014, 48, 10776-10784. [CrossRef] [PubMed]

20. Serrenho, A.C.; Allwood, J.M. Material Stock Demographics: Cars in Great Britain. Environ. Sci. Technol. 2016, 50, 3002-3009. [CrossRef]

21. Busch, J.; Steinberger, J.K.; Dawson, D.A.; Purnell, P.; Roelich, K. Managing Critical Materials with a Technology-Specific Stocks and Flows Model. Environ. Sci. Technol. 2014, 48, 1298-1305. [CrossRef] [PubMed]

22. Busch, J.; Dawson, D.; Roelich, K. Closing the low-carbon material loop using a dynamic whole system approach. J. Clean. Prod. 2017, 149, 751-761. [CrossRef]

23. Elshkaki, A. An analysis of future platinum resources, emissions and waste streams using a system dynamic model of its intentional and non-intentional flows and stocks. Resour. Policy 2013, 38, 241-251. [CrossRef]

24. Majeau-Bettez, G.; Hawkins, T.R.; Strømman, A.H. Life Cycle Environmental Assessment of Lithium-Ion and Nickel Metal Hydride Batteries for Plug-In Hybrid and Battery Electric Vehicles. Environ. Sci. Technol. 2011, 45, 4548-4554. [CrossRef] [PubMed]

25. Restrepo, E.; Løvik, A.N.; Wäger, P.; Widmer, R.; Lonka, R.; Müller, D.B. Stocks, Flows, and Distribution of Critical Metals in Embedded Electronics in Passenger Vehicles. Environ. Sci. Technol. 2017, 51, 1129-1139. [CrossRef] [PubMed]

26. Sun, Y.; Delucchi, M.; Ogden, J. The impact of widespread deployment of fuel cell vehicles on platinum demand and price. Int. J. Hydrogen Energy 2011, 36, 11116-11127. [CrossRef]

27. Yano, J.; Muroi, T.; Sakai, S. Rare earth element recovery potentials from end-of-life hybrid electric vehicle components in 2010-2030. J. Mater. Cycles Waste Manag. 2016, 18, 655-664. [CrossRef]

28. The Economist. The Driverless, Car-Sharing Road Ahead. The Economist, 9 January 2016. Available online: https: / / www.economist.com/news/business/21685459-carmakers-increasingly-fret-their-industrybrink-huge-disruption (accessed on 17 January 2018).

29. Musk, E. Hyperloop Alpha; SpaceX: Hawthorne, CA, USA, 2013; Available online: http:/ /www.spacex.com/ sites/spacex/files/hyperloop_alpha.pdf (accessed on 17 January 2018).

30. Sims, Z.C.; Weiss, D.; McCall, S.K.; McGuire, M.A.; Ott, R.T.; Geer, T.; Rios, O.; Turchi, P.A.E. Cerium-Based, Intermetallic-Strengthened Aluminum Casting Alloy: High-Volume Co-product Development. JOM 2016, 68, 1940-1947. [CrossRef]

31. Sims, Z.C.; Rios, O.R.; Weiss, D.; Turchi, P.E.A.; Perron, A.; Lee, J.R.I.; Li, T.T.; Hammons, J.A.; Bagge-Hansen, M.; Willey, T.M.; et al. High performance aluminum-cerium alloys for high-temperature applications. Mater. Horiz. 2017, 4, 1070-1078. [CrossRef]

32. Modaresi, R.; Løvik, A.N.; Müller, D.B. Component- and Alloy-Specific Modeling for Evaluating Aluminum Recycling Strategies for Vehicles. JOM 2014, 66, 2262-2271. [CrossRef]

33. U.S. Geological Survey. Rare Earth Elements-Critical Resources for High Technology; U.S. Geological Survey: Reston, VA, USA, 2002.

34. Nguyen, R.T.; Imholte, D.D. China's Rare Earth Supply Chain: Illegal Production, and Response to new Cerium Demand. JOM 2016, 68, 1948-1956. [CrossRef]

35. Elshkaki, A.; van der Voet, E.; Timmermans, V.; Holderbeke, M.V. Dynamic stock modelling: A method for the identification and estimation of future waste streams and emissions based on past production and product stock characteristics. Energy 2005, 30, 1353-1363. [CrossRef]

36. Fishman, T.; Schandl, H.; Tanikawa, H.; Walker, P.; Krausmann, F. Accounting for the Material Stock of Nations. J. Ind. Ecol. 2014, 18, 407-420. [CrossRef] [PubMed] 
37. Hatayama, H.; Daigo, I.; Matsuno, Y.; Adachi, Y. Outlook of the World Steel Cycle Based on the Stock and Flow Dynamics. Environ. Sci. Technol. 2010, 44, 6457-6463. [CrossRef] [PubMed]

38. Krausmann, F.; Wiedenhofer, D.; Lauk, C.; Haas, W.; Tanikawa, H.; Fishman, T.; Miatto, A.; Schandl, H.; Haberl, H. Global socioeconomic material stocks rise 23-fold over the 20th century and require half of annual resource use. Proc. Natl. Acad. Sci. USA 2017, 114, 1880-1885. [CrossRef] [PubMed]

39. Van der Voet, E.; Kleijn, R.; Huele, R.; Ishikawa, M.; Verkuijlen, E. Predicting future emissions based on characteristics of stocks. Ecol. Econ. 2002, 41, 223-234. [CrossRef]

40. Laner, D.; Rechberger, H.; Astrup, T. Systematic Evaluation of Uncertainty in Material Flow Analysis. J. Ind. Ecol. 2014, 18, 859-870. [CrossRef]

41. Liu, G.; Müller, D.B. Centennial Evolution of Aluminum In-Use Stocks on Our Aluminized Planet. Environ. Sci. Technol. 2013, 47, 4882-4888. [CrossRef] [PubMed]

42. OECD/International Transport Forum. Long-run Trends in Car Use. In ITF Round Tables; No. 152; OECD Publishing/ITF: Paris, France, 2013; ISBN 978-92-821-0593-1. [CrossRef]

43. Volvo Car Group. Volvo Cars to Go All Electric. 5 July 2017. Available online: https:/ /www.media.volvocars. com/global/en-gb/media/pressreleases/210058/volvo-cars-to-go-all-electric (accessed on 15 October 2017).

44. General Motors. GM Outlines All-Electric Path to Zero Emissions. 2 October 2017. Available online: http: / /www.gm.com/mol/m-2017-oct-1002-electric.html (accessed on 15 October 2017).

45. Reuters. Automakers Get Serious about Electric Cars. Reuters, 17 November 2017. Available online: https:/ / www.reuters.com/article/us-autos-electric-factbox/factbox-automakers-get-serious-about-electriccars-idUSKBN1DH28A (accessed on 18 November 2017).

46. National Conference of State Legislatures State Efforts to Promote Hybrid and Electric Vehicles. Available online: http:/ / www.ncsl.org/research/energy/state-electric-vehicle-incentives-state-chart.aspx (accessed on 15 October 2017).

47. International Energy Agency. Energy Technology Perspectives 2008: Scenarios E Strategies to 2050; IEA Publications: Paris, France, 2008.

48. Miatto, A.; Schandl, H.; Tanikawa, H. How important are realistic building lifespan assumptions for material stock and demolition waste accounts? Resour. Conserv. Recycl. 2017, 122, 143-154. [CrossRef]

49. National Highway Traffic Safety Administration. Vehicle Survivability and Travel Milage Schedules; NHTSA Technical Report; U.S. Department of Transportation: Springfield, VA, USA, 2006.

50. Alonso, E.; Wallington, T.; Sherman, A.; Everson, M.; Field, F.; Roth, R.; Kirchain, R. An assessment of the rare earth element content of conventional and electric vehicles. SAE Int. J. Mater. Manuf. 2012, 5, $473-477$. [CrossRef]

51. Alonso, E.; Sherman, A.M.; Wallington, T.J.; Everson, M.P.; Field, F.R.; Roth, R.; Kirchain, R.E. Evaluating Rare Earth Element Availability: A Case with Revolutionary Demand from Clean Technologies. Environ. Sci. Technol. 2012, 46, 3406-3414. [CrossRef] [PubMed]

52. Borgwardt, R.H. Platinum, fuel cells, and future US road transport. Transp. Res. Part D Transp. Environ. 2001, 6, 199-207. [CrossRef]

53. Chan, C.C.; Bouscayrol, A.; Chen, K. Electric, hybrid, and fuel-cell vehicles: Architectures and modeling. IEEE Trans. Veh. Technol. 2010, 59, 589-598. [CrossRef]

54. Cheah, L.; Heywood, J.; Kirchain, R. The energy impact of US passenger vehicle fuel economy standards. In Proceedings of the IEEE International Symposium on Sustainable Systems and Technology (ISSST), Arlington, VA, USA, 17-19 May 2010; pp. 1-6.

55. Cullbrand, K.; Magnusson, O. The Use of Potentially Critical Materials in Passenger Cars; Chalmers University of Technology: Gothenburg, Sweden, 2012.

56. Du, X.; Restrepo, E.; Widmer, R.; Wäger, P. Quantifying the distribution of critical metals in conventional passenger vehicles using input-driven and output-driven approaches: A comparative study. J. Mater. Cycles Waste Manag. 2015, 17, 218-228. [CrossRef]

57. Ellingsen, L.A.-W.; Majeau-Bettez, G.; Singh, B.; Srivastava, A.K.; Valøen, L.O.; Strømman, A.H. Life Cycle Assessment of a Lithium-Ion Battery Vehicle Pack. J. Ind. Ecol. 2014, 18, 113-124. [CrossRef]

58. Hawkins, T.R.; Singh, B.; Majeau-Bettez, G.; Strømman, A.H. Comparative Environmental Life Cycle Assessment of Conventional and Electric Vehicles. J. Ind. Ecol. 2013, 17, 53-64. [CrossRef]

59. Hawkins, T.R.; Singh, B.; Majeau-Bettez, G.; Strømman, A.H. Corrigendum to: Comparative environmental life cycle assessment of conventional and electric vehicles. Ind. Ecol. 2013, 17, 158-160. [CrossRef] 
60. TIAX LLC. Platinum Availability and Economics for PEMFC Commercialization; Report to US Department of Energy; TIAX LLC: Cambridge, MA, USA, 2003. Available online: http:/ / www1.eere.energy.gov / hydrogenandfuelcells / pdfs/tiax_platinum.pdf (accessed on 15 September 2016).

61. Tollefson, J. Worth its weight in platinum: Booming mineral prices leave car makers scrambling to eke more catalytic performance out of precious metals. Nature 2007, 450, 334-336. [CrossRef] [PubMed]

62. U.S. Department of Energy. Alternative Fuels Data Center. Available online: https://www.afdc.energy.gov/ data / (accessed on 20 November 2016).

63. U.S. Department of Energy. AVTA: Light Duty Alternative Fuel and Advanced Vehicle Data. Available online: https: / / energy.gov/eere/vehicles/avta-light-duty-alternative-fuel-and-advanced-vehicle-data (accessed on 20 November 2016).

64. Kelly, T.D.; Matos, G.R. Historical Statistics for Mineral and Material Commodities in the United States. U.S. Geological Survey Rare Earth Statistics [Through 2015, Last Modified 19 January 2017]. Available online: https:/ / minerals.usgs.gov/minerals/pubs/historical-statistics / /\#rareearths (accessed on 8 June 2017).

65. U.S. Geological Survey. Mineral Commodity Summaries 2017, 2017th ed.; U.S. Geological Survey: Reston, VA, USA, 2017.

66. Goonan, T.G. Rare Earth Elements-End Use and Recyclability: U.S. Geological Survey Scientific Investigations Report 2011-5094; U.S. Geological Survey: Reston, VA, USA, 2011.

67. Binnemans, K.; Jones, P.T. Rare Earths and the Balance Problem. J. Sustain. Metall. 2015, 1, 29-38. [CrossRef]

68. Elshkaki, A.; Graedel, T.E. Dysprosium, the balance problem, and wind power technology. Appl. Energy 2014, 136, 548-559. [CrossRef]

69. Gordon, R.B.; Bertram, M.; Graedel, T. Metal stocks and sustainability. Proc. Natl. Acad. Sci. USA 2006, 103, 1209-1214. [CrossRef] [PubMed]

70. Rauch, J.N. Global mapping of $\mathrm{Al}, \mathrm{Cu}, \mathrm{Fe}$, and $\mathrm{Zn}$ in-use stocks and in-ground resources. Proc. Natl. Acad. Sci. USA 2009, 106, 18920-18925. [CrossRef] [PubMed]

71. Sverdrup, H.U.; Ragnarsdottir, K.V.; Koca, D. Aluminium for the future: Modelling the global production, market supply, demand, price and long term development of the global reserves. Resour. Conserv. Recycl. 2015, 103, 139-154. [CrossRef]

72. Gruber, P.W.; Medina, P.A.; Keoleian, G.A.; Kesler, S.E.; Everson, M.P.; Wallington, T.J. Global Lithium Availability. J. Ind. Ecol. 2011, 15, 760-775. [CrossRef]

73. Simon, B.; Ziemann, S.; Weil, M. Potential metal requirement of active materials in lithium-ion battery cells of electric vehicles and its impact on reserves: Focus on Europe. Resour. Conserv. Recycl. 2015, 104, 300-310. [CrossRef]

74. Narins, T.P. The battery business: Lithium availability and the growth of the global electric car industry. Extr. Ind. Soc. 2017, 4, 321-328. [CrossRef]

75. Ali, S.H.; Giurco, D.; Arndt, N.; Nickless, E.; Brown, G.; Demetriades, A.; Durrheim, R.; Enriquez, M.A.; Kinnaird, J.; Littleboy, A.; et al. Mineral supply for sustainable development requires resource governance. Nature 2017, 543, 367-372. [CrossRef] [PubMed]

76. Simas, M.; Pauliuk, S.; Wood, R.; Hertwich, E.G.; Stadler, K. Correlation between production and consumption-based environmental indicators: The link to affluence and the effect on ranking environmental performance of countries. Ecol. Indic. 2017, 76, 317-323. [CrossRef]

77. Wiedmann, T.O.; Schandl, H.; Lenzen, M.; Moran, D.; Suh, S.; West, J.; Kanemoto, K. The material footprint of nations. Proc. Natl. Acad. Sci. USA 2015, 122, 6271-6276. [CrossRef] [PubMed]

78. RTTNews. Reuters: GM May Cancel Six Car Models In U.S., Including Chevrolet Volt. Business Insider. 2017. Available online: http:/ / markets.businessinsider.com/news/stocks/Reuters-GM-May-Cancel-SixCar-Models-In-U-S-Including-Chevrolet-Volt-1002196631 (accessed on 3 August 2017).

(C) 2018 by the authors. Licensee MDPI, Basel, Switzerland. This article is an open access article distributed under the terms and conditions of the Creative Commons Attribution (CC BY) license (http://creativecommons.org/licenses/by/4.0/). 